\title{
NOTES ON THE BRYOPHYTES OF MADAGASCAR 2. NEW LIVERWORT AND HORNWORT RECORDS
}

\author{
Tamás Pócs \\ Institute of Biology, Eszterházy Károly University, Eger, Pf. 43, Hungary, H-3301; \\ E-mail: pocs.tamas33@gmail.com
}

\begin{abstract}
During the identification of the epiphyllous liverworts collected in Madagascar for the purposes of description of foliicolous communities, 11 species turned out as new to the flora of the island, one of them (Cololejeunea ocelloides) to the whole of Africa. In addition, 8 other species hitherto known only from one place in Madagascar became known from other localities. Finally two new synonyms were established.
\end{abstract}

Keywords: biodiversity, endemics, Indian Ocean islands, Madagascar, new species

\section{INTRODUCTION}

The author with colleagues from the Eger College and other institutions and with his late wife visited Madagascar during 1990, 1994, 1998 and in 2004. The results of these collecting trips are only partly published (Allen and Magill 2007, Bechteler et al. 2015, Dong et al. 2012, 2013, Dorr 1997, He and Grolle 2001, Heinrichs et al. 2005, 2014, Hodgetts 2008, Jones 1992, Kis and Pócs 2006, Lee et al. 2015, Lee and Pócs 2018, Lindner et al. 2004, Orbán 1995, 2000, Pócs 1995, 1997, 2001, 2004, 2006a, 2006b, 2006c, 2010a, 2010b, 2011a, 2011b, 2011c, 2020a, 2020b, 2021, Pócs et al. 2015, 2016, 2018, 2019, Pócs and Geissler 2002, Pócs and Sass-Gyarmati 2006, Pócs and Schäfer-Verwimp 2006, Pócs and Váňa 2002, 2015, Reeb et al. 2018, 2019, Sass-Gyarmati 2001, 2017, Sass-Gyarmati and Pócs 2002, 2019, Szabó and Pócs 2016, Wilding 2016), which were summarized until 2011 in Marline et al. (2012). Another part of the specimens is still under identification by himself and by specialists of the concerned groups [S.R. Gradstein (GOET): Plagiochila, G.E. Lee: Lejeunea, A.E. Newton (BR): Rutenbergiaceae, 
A. Sass-Gyarmati (EGR): Bazzania, J. Wilbraham (BM): Orthotrichaceae].

\section{MATERIALS AND METHODS}

In the following the author wishes to display records from his most recent investigations done mostly on epiphyllous liverwort communities. Some of them are widely distributed in the continental part of Africa but somehow were not yet reported from Madagascar. For the nomenclature the 'World checklist of hornworts and liverworts' (Söderström et al. 2016) was considered. In the Madagascar and total African distribution apart from smaller reports we took in account the publications of Marline et al. (2012) and of Wigginton (2018). Specimens of the collection are deposited in the herbarium of Eszterházy Károly University in Eger, Hungary (EGR), in the Tsimbazaza Botanic Garden Herbarium (TAN), partly also in the Missouri Botanic Garden Herbarium (MO) and in the Herbarium of Field Museum in Chicago (F). Our present records originate from only a few localities and almost all are epiphylls (if not otherwise stated), therefore it seemed to be reasonable to enumerate the localities first in details than in the list just to mention them by their collecting numbers:

\section{The collecting localities}

90111. Antsiranana prov., Sava reg., Réserve Intégrale Nationale de Marojezy. Lowland rainforest near the first campsite in Andampibe valley, 200-500 m, with giant trees. T. Pócs, with R.E. Magill \& C. LaFarge-England, 23-24. March 1990.

90113. Antsiranana prov., Sava reg.,réserve Intégrale Nationale de MAROJEZY. Montane rainforest on the ridge $\mathrm{N}$ of Andampibe falls, 780-1050 m., trees 10-20 m high with many epiphytes. T. Pócs, with R.E. Magill \& C. LaFarge-England, 24-29. March 1990.

90114. Antsiranana prov., Sava reg., réserve Intégrale Nationale de Marojezy. Elfin forest on the SE ridge near camp III, at $1830 \mathrm{~m}$ alt. T. Pócs, with R.E. Magill \& C. LaFarge-England, 26-28. March 1990.

9448. Antsiranana prov., Sava reg. Masoala Peninsula. Submontane rainforest on the W slopes E of AMBANIZANA village, $450-600 \mathrm{~m}, 1^{\circ} 37^{\prime} \mathrm{S}, 49^{\circ} 59^{\prime} 30^{\prime \prime E}$. T. Pócs, G. Kis, 9. Sept. 1994.

9472. Fianarantsroa Prov., Haute Matsiatra reg., Parc national de l'Andringitra . Montane rainforests on the $\mathrm{W}$ side of KOROKORO river, around camp II, 750-1000 m, 22¹3'S, 4701-02'E. T. Pócs, G. Kis \& A. Szabó, 20-23. Sept. 1994.

9473. Fianarantsroa prov., Haute Matsiatra reg., Parc national de l'Andringitra. Mossy montane rainforest along a W tributary of KOROKORO river, near camp III, 1000-1270 m, 22²'40"S, 470 E . T. Pócs, G. Kis \& A. Szabó, 20-23. Sept. 1994. 
9474. Fianarantsroa prov., Haute Matsiatra, Parc national de l'Andringitra. Mesic montane evergreen forest on the ridge E of camp III, 1270-1450 m, with many climbing bamboos (Nastus sp.), 22¹2'30"S, 470'15"E. T. Pócs, 22. Sept. 1994.

9875. Toamasina prov., Analanjirofo reg., Mananara Nord Biosphere Reserve. Perhumide coastal dune forest with rich moss layer on the sandy ground, $1 \mathrm{~km} \mathrm{~W}$ of Antanambe village, $5 \mathrm{~m}, 1^{\circ} 25.8^{\prime}$ S, 4950.2'E. K., S. \& T. Pócs and A. Szabó, 13. Aug. 1998.

9877. Toamasina prov., Analanjirofo reg., Mananara Nord Biosphere Reserve and National Park. Lowland rainforest on the NW slope of BEHAFOTRA hill, 250-300 m, with $3500 \mathrm{~mm}$ annual rainfall, 16²7.1-3'S, 4947.6-9'E. K. \& T. Pócs and A.\& E. Szabó, 14-16. Aug. 1998.

9883. Toamasina prov., Atsinanana reg.. Coastal dune forest with stilt rooted Uapaca trees and Memecylon bushes along the road between Andovoranto and Ambila-Lemaitso, 4-5 m , 1854.2-55.4’S, 49³.3-6’E. S. \& T. Pócs and A. Szabó, 22. Aug. 1998.

9887. Toamasina prov, Atsinanana reg. Peat forest \& woodland often with thick Sphagnum layer on coastal white sand, with shallow lakes, between Pampangalana Canal and the ocean, $5 \mathrm{~km} \mathrm{~N}$ of Andovoranto, between Andombo and Andovoa, 10 M , 1854.1'S, 497.24'E. Pócs And A. Szabó, 24. Aug. 1998.

9888. Toamasina prov., Atsinanana reg. Open dune forest dominated by Pandanus sp. and Garcinia sp. on coastal white sands between Pampangalana canal and the ocean, $5 \mathrm{~km} \mathrm{~N}$ of Andovoranto, between Andombo and Andovoa, at $10 \mathrm{~m}$ alt. 1854.1'S, 49².24'E. T. Pócs and A. Szabó, 24. Aug. 1998.

9890. Toamasina prov., Alaotra-Mangoro, reg. Maromizaha forest, mossy montane rainforest with bamboo (Nastus sp.) undergrowth on the summit ridge of Mt. Maromizaha, south of the Andasibe Nat. Park and the Antananarivo - Toamasina road, $2 \mathrm{~km}$ SW of Anevoka village, 1080-1214 m , 18²57.8'S, $48^{\circ} 27.5^{\prime}$ E. S. \& T. Pócs, 26. Aug. 1998.

04116. Fianarantsoa prov. Forest Reserve on the E side of Antananarivo Fianarantsoa road, $5 \mathrm{~km} \mathrm{~N}$ of Ambohima-Hasoa town, $\mathrm{S}$ of Ialatsara village. Eucalyptus plantation replacing montane rainforest, $1360 \mathrm{~m}$ alt. $21^{\circ} 04.69^{\prime} \mathrm{S}$, 47¹2.70’E. S.\& T. Pócs, N. Rakotonirina, R. Ranaivojaona and Z. Tuba, 24 July 2004.

04120. Fianarantsoa prov., Atsinanana reg; parc National de Ranomafana. Sahamalaotra Forest, $1.5 \mathrm{~km}$ E of Vohiparara village. Montane rainforest on undulating terrain, $1120-1160 \mathrm{~m}, 21^{\circ} 14.36^{\prime} \mathrm{S}, 4^{\circ} 23.67^{\prime} \mathrm{E}$. T. Pócs, N. Rakotonirina \& R. Ranaivojaona, 26 July 2004.

04126. Fianarantsoa prov., Atsinanana reg; parc National de Ranomafana. Along the $\mathrm{N}$ side of main road at the head the big waterfalls on the NAMORONA river. Dripping granitic cliffs surrounded by montane rainforest, $1080-1150 \mathrm{~m}$, 21ำ14.70-86’S, 47²3.82’E. S. \& T. Pócs, 29 July 2004.

04128. Fianarantsoa prov., Atsinanana reg;, parc National de Ranomafana. On the summit ridge of Mt. Vatolampy (with a telecom aerial), $2.3 \mathrm{~km} \mathrm{~W}$ of Ambatolahy village. Disturbed, relatively open montane rainforest with 5-10 $(-20) \mathrm{m}$ high trees, rich in micro-epipytes, $1200 \mathrm{~m}, 2^{\circ} 15.10^{\prime}$ S, 47 $24.44^{\prime}$ E S.\& T. Pócs, 30 July 2004.

04130. Fianarantsoa prov., Atsinanana reg; beyond the $W$ boundary of Ranomafana National park. $1.6 \mathrm{~km}$ E of Ambatovaku Avaratra village, on the S side ridge of Mt. Namatoana. Dense, but not too shady microphyllous elfin forest of 
thin, 6-8 (10) m tall trees, 1250 m,. 21ำ17.10’S, 47¹9.14’'E. S. \& T. Pócs, K. Tuba, 24 July 2004 .

\section{RESULTS}

\section{Records new for Madagascar}

Caudalejeunea africana (Steph.) Steph. 90111/BB, 9875/CC. Widespread epiphyll in continental Africa, new to the Indian Ocean islands, including Madagascar.

Cheilolejeunea adnata (Lehm.) Grolle var. autoica Gradst. \& Ilk.-Borg. (Syn.: Cheilolejeunea larsenii Mizut., Cheilolejeunea exinnovata E.W. Jones (fide Bastos \& Gradstein 2020). 90111/CE, a pantropical species hitherto known from several places in continental West-Africa and Zimbabwe under the name of $C$. larsenii, but new for all East African islands (Wigginton 2018). It is characterized by its bottle shaped lobule and the the variability of its teeth often crossing each other.

Cheilolejeunea ventricosa (Schiffn. ex P.Syd.) Xiao L. He. 9472/BV, on dry, dead leaf. Malesian-Pacific species known in Africa only from Mauritius (Pócs 1997 as Pycnolejeunea ventricosa, Pócs et al. 2019).

Cololejeunea haskarliana (Lehm. et Lindenb.) Schiffn. 90113/FL, 9472/AS, 9473/GV, 9474/AA. A widespread species in Asia and in the Pacific, but in Africa only known from the Seychelles and from Réunion Island.

Cololejeunea ocelloides (Hook.) Mizut. (Syn.: Cololejeunea leonidens Benedix). 90114/KE. Hitherto known as a Malesian species known from Sumatra to New Guinea (Pócs and Piippo 2011), new for Africa.

Cololejeunea pteroporum Tixier 90111/BR. A species described and hitherto known only from Rodrigues Island (Tixier 1985, Grolle 1995), new for Madagascar.

Dendroceros borbonicus Steph. 9888/F. Quite widespread in Mauritius, Réunion and the Seychelles, not yet known from Madagascar. A species equally occurring on leaves, bark and twigs in wet habitats.

Lejeunea exilis (Reinw. et al.) Grolle 90114/HA. A widespread Indomalesian-Pacific species, known only from Réunion in Africa, new for Madagascar. 

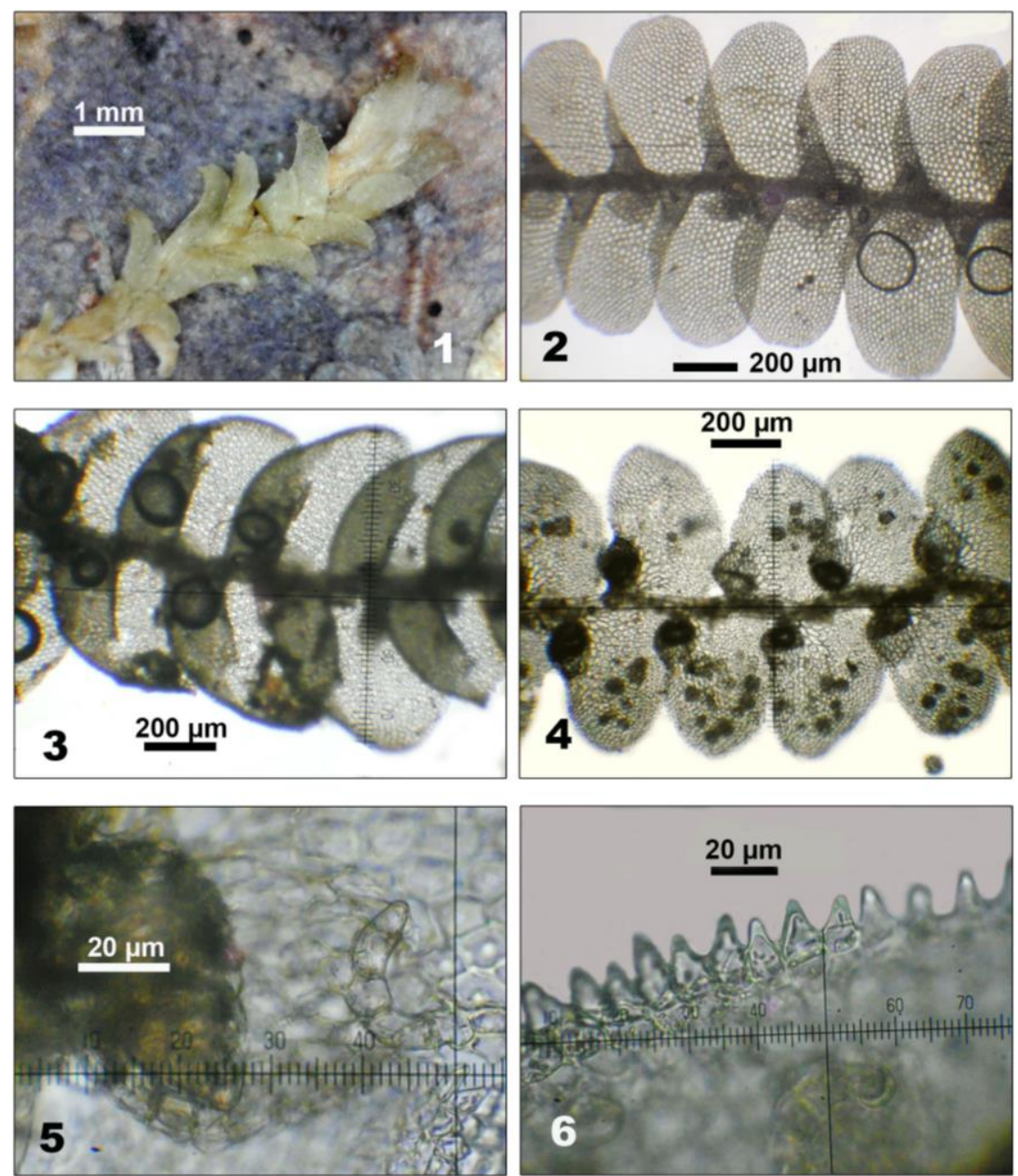

Plate I. Figure 1. Caudalejeunea africana (Steph.) Steph. (from Pócs \& Szabó 9875/CC). Figure 2. Cheilolejeunea andnata var. autoica Gradst. \& Ilkiu-Borges, ventral view (from Pócs 90111/CE). Figure 3. Cheilolejeunea ventricosa (Schiffn. ex P.Syd.) Xiao L. He, ventral view (from T. Pócs \& Kis 9472/BV). Figures 4-6. Cololejeunea haskarliana (Lehm. \& Lindenb.) Steph., $4=$ ventral view, $5=$ lobule with crossing teeth, 6 = lobe margin (from Pócs \& Kis 9472/AS).

Leptolejeunea maculata (Mitt.) Schiffn. 94111/BC,BW, 9883/BA. A palaeotropic species, widespread in mainland Africa and tropical Asia and the Pacific, known also from the Seychelles, Réunion and Rodrigues Island but not yet in Madagascar (Müller and Pócs 2002). 
Microlejeunea dispar Jov.-Ast 90113/FO. Endemic of the East African islands, known only from Réunion, Mauritius (Grolle 1995, Marline et al. 2012, Wigginton 2018).

Radula flaccida (Lindenb.) Gottsche 90111/BH, 9883/BR. A common Afro-American epiphyll. From the Indian Ocean region it was known only from Anjouan (Dzouani) Island in the Comores (Castle 1939).

Records of species known before only from one area in Madagascar

Cololejeunea mariana Tixier 90111/CG. Known only from its type locality in St. Marie Island.

Colura obvoluta Jov.-Ast 9875/CN. Apart from its type locality in St. Marie Island of Madagascar it was known only from the Seychelles Islands (Pócs 1995).

Colura humbertii Jov.-Ast 9890/DB. In Pócs (2020b) this record by mistake under the name of $C$. calyptrifolia was communicated. 04126/QC. In Madagascar it is known only from its type locality (Jovet-Ast 1954). Since became known from Mauritius and Réunion (Grolle 1995) and from Tanzania (Pócs 2020b).

Diplasiolejeunea magnistipula Tixier 04128/AT. The species was described from Cameroon (Tixier 1975) and later only one other record was published from the Lokoho Basin in northern Madagascar (under the synonym of Diplasiolejeunea drepanolejeuneoides, Tixier 1977).

Drepanolejeunea cultrella (Mitt.) Steph. 04128/AT. On dry, dead leaf. A very widespread tropical African species known only from one locality in north-western Madagascar (Pócs and Geissler 2002).

Leptolejeunea epiphylla (Mitt.) Steph. 94111/BC. Palaeotropical species, widespread from tropical Africa through tropical Asia to the Pacific. It is known in the Indian Ocean Islands from the Seychelles, Comores and Mauritius and in Madascar only from the Manongarivo Reserve (Pócs and Geissler 2002).

Otolejeunea moniliata Grolle. 9448/K, 9472/AD, AZ epiphyllous, BW On dry, dead leaves. It was previously known only from the type area of Marojezy Reserve in northern Madagascar. Now it becomes known also from the Masoala Peninsula and further south in the Andringitra mountains. It is worth to mention 
that the original description does not mention the scattered ocelli, which can be observed only on fresh material (and also seen on the micrograph of Bechteler et al. 2015: fig. 1c and f). Furthermore there are specimens with denticulate lobes, where the teeth are tipped by hyaline papillae.
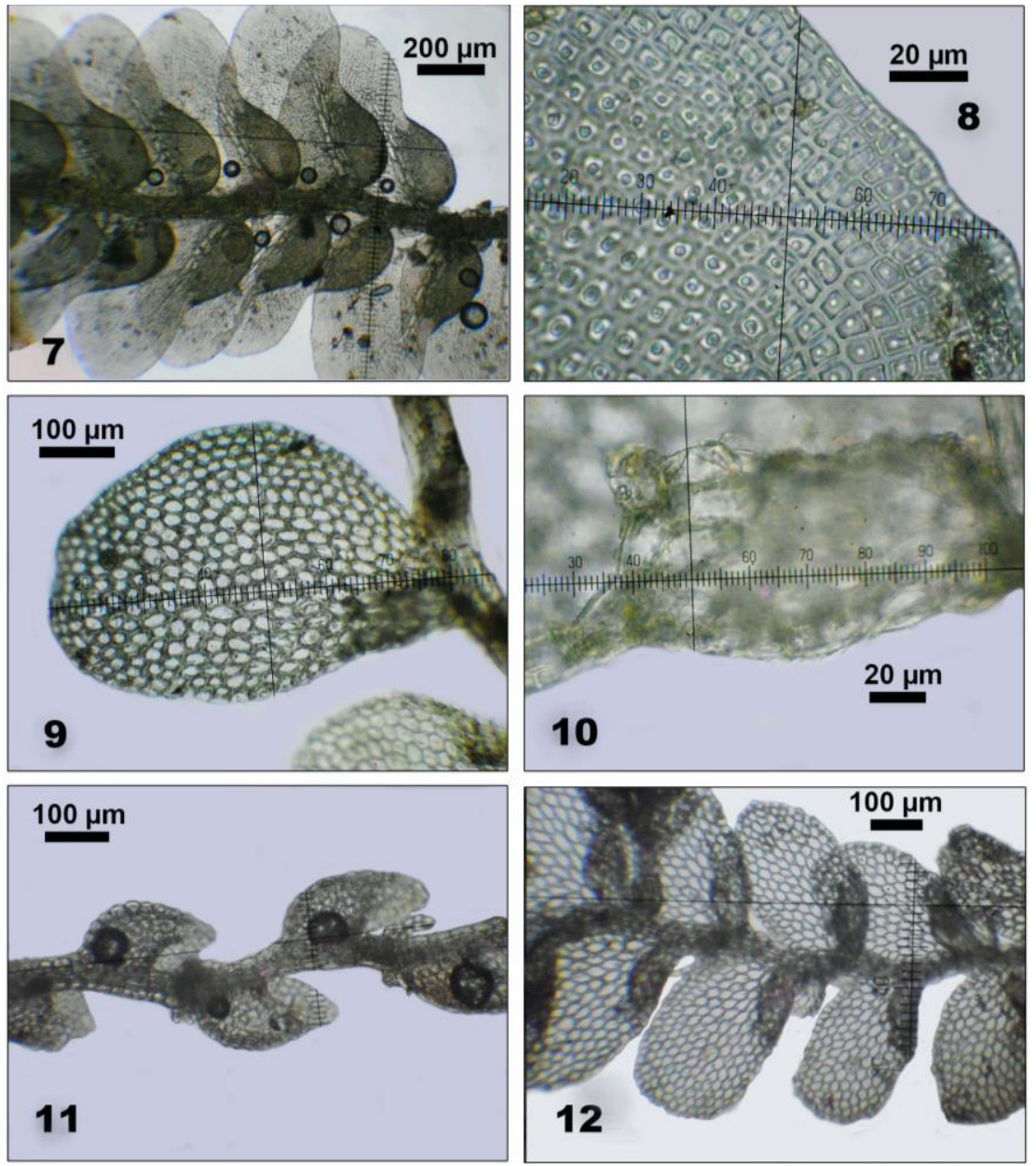

Plate II. Figures 7-8. Cololejeunea ocelloides (Hook.) S.Hatt. 7 = ventral view, $8=$ lobe margin (from Pócs et al. 90114/KE). Figures 9-10. Cololejeunea pteroporum Tixier, 9 = leaf, dorsal view, 10 = lobule, ventral view (from Pócs et al. 90111/BR). Figure 11. Lejeunea exilis (Reinw. et al.) Grolle, ventral view (from Pócs et al. 90114/HA). Figure 12. Leptolejeunea maculata (Mitt.) Schiffn., ventral view (from Pócs \& Szabó 9883/BA). 
Radula pinnata Pócs 9875/CK. New record of the recently described species (Pócs 2020a) at $5 \mathrm{~km}$ distance from the type locality. It was supposed that it is mainly corticolous and only facultative or incidentally epiphyll, but at the new locality $R$. pinnata occurred also only on leaf surface.
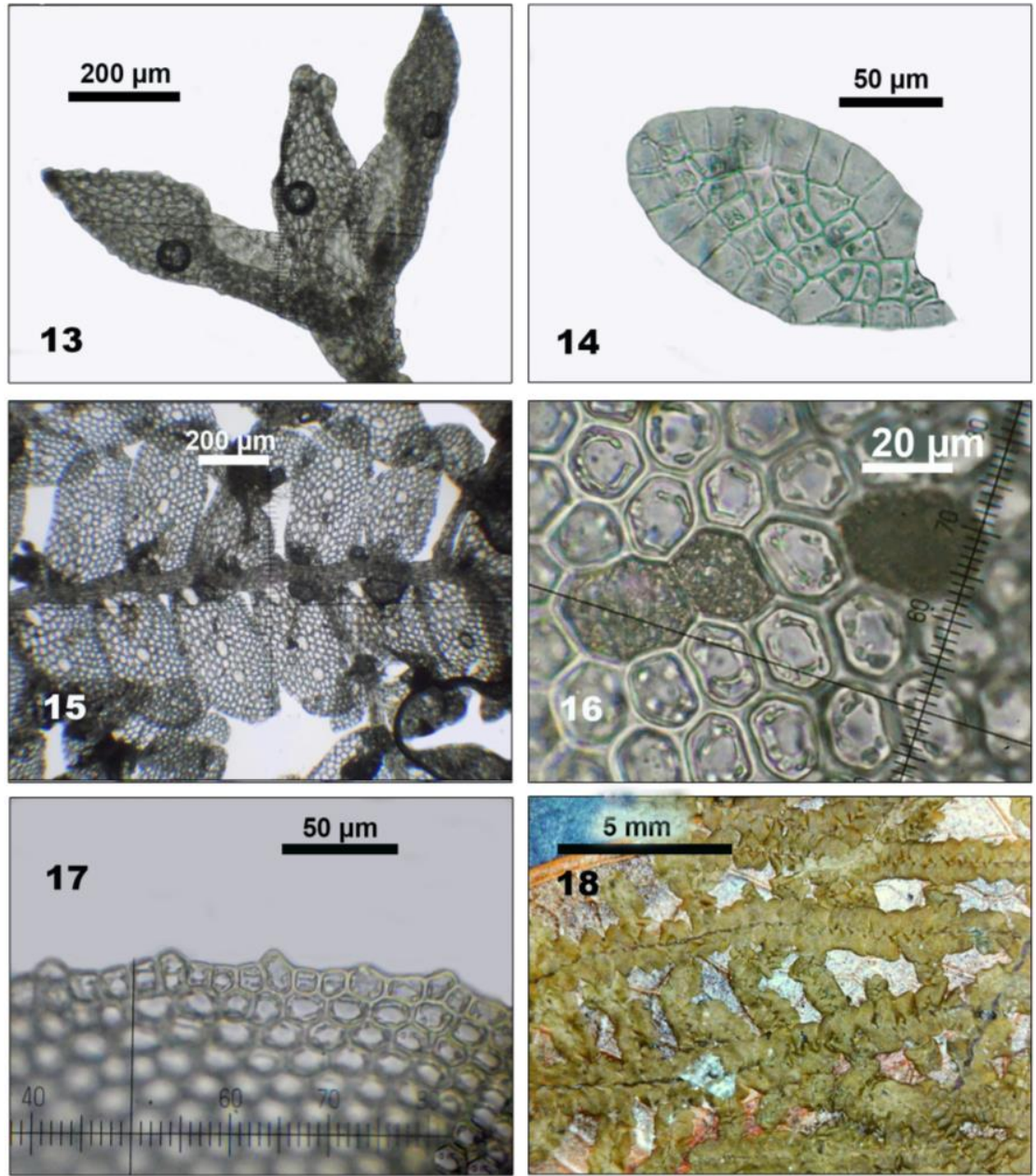

Plate III. Figures 13-14. Colura obvoluta Jov.-Ast , 12 = ventral view, $14=$ unseparable valve (from Pócs \& Szabó 9875/CN). Figure 15. Leptolejeunea maculata (Mitt.) Schiffn., ventral view from Pócs et al. 90111/BC). Figures 16-17. Otolejeunea moniliata Grolle. 16 = scattered mid lobe ocelli, 17 = sparsely denticulate lobe margin (from Pócs et al. 9472/AZ). Figure 18. Radula pinnata Pócs (from Pócs et al. 9875/CK). 


\section{New synonyms of Madagascar liverworts}

During the study of many epiphyllous material from different Madagascar localities was found that some species described on the base of only few specimens are interconnected by transitional forms. Hence is impossible to demarcate species limits between them. On this base the following new synonyms were established:

Cololejeunea cuneata (Lehm. et Lindenb.) Herzog, Bot. Not. 100 (4): 320, 1947 (Herzog 1947).

Basionym: Jungermannia cuneata Lehm. et Lindenb., Nov. Stirp. Pug. 4: 56, 1832 (Lehmann 1832). Type: MAURITIUS (G).

Syn.: Leptocolea subciliata (Mitt.) E.W.Jones, Trans Brit. Bryol. Soc. 2 (E.W. Jones 1953). Type: RODRIGUEZ I. I.B. Balfour, 1874 (BM).

Syn. nov.: Cololejeunea cristata (Steph.) R.M. Schust. Beih. Nova Hedwigia 9: 173, 1963 (Schuster 1963).

Basionym: Physocolea cristata Steph., Sp. Hepat. (Stephani) 5: 869, 1916 (Stephani 1916).

Type: MADAGASCAR Leloutre, 13 July 1898 (G).

Other synonyms see in Tixier (1985).

Tixier (1985: 52) had already mentioned the difficulties to distinguish Cololejeunea cristata from Cololejeunea cuneata and from some other species. The difference between the two species is established on the lobule dentition, whether 1 or 2 lobule teeth are present. In our collections (90111/BQ, 90113/FU, 9473/HJ, $9875 \mathrm{CH}, 9883 / \mathrm{BC}, 9887 / \mathrm{Y}$ ), even within one specimen, both cases occur and the development of second tooth is very variable, from very well developed to obsolete or nothing. This indicates that the two species are practically not separable.

Diplasiolejeunea kraussiana (Lindenb.) Spruce, Sp. Hepat. (Stephani) 5: 919, 1916 (Stephani 1916).

Basionym.: Lejeunea kraussiana Lindenb., Syn. Hepat. 3: 393, 1845, (Gottsche et al. 1845).

Type: SOUTH AFRICA, near Knysna, in terries "Outaniquanis", Krauss (W, Lindenb. Hep. 6757, isotypes BM (H 10003), G).

Syn. nov.: Diplasiolejeunea auriculata Tixier, Rev. Bryol. Lichenol. 45 (2): 210, 1979 (Tixier 1979).

Type: MADAGASCAR, Fianarantsdoa, forêt du Tsarafidy, Tixier 8908 (holotype PC). 
According to Tixier (1979:212) D. auriculata is close to $D$. kraussiana. To distinguish the two species, he used the formation of lobule apex and the shape of perianths. In the original diagnosis of Diplasiolejeunea kraussiana (Lindenberg in Gottsche et al. 1845), the lobule apex is described as "lobulo magno bidentato (dente margini propinquo maiore) inflexo". Tixier writes in the diagnosis of Diplasiolejeunea auriculata: "dente media cum duobus cellulis ad apicem". The T shaped teeth, like for Diplasiolejeunea cornuta Steph., is a very unreliable character occurring on many lobules indeed and missing in others, within the same or in other plants. The perianth shape is also very variable, even on the Tixier's drawings of (1979: 211-212, figs. 1:11 and fig 2: 10-12) from obcordate with auriculate wings to simple obconic with narrow, straight wings. According to the author's observation several specimens are transitional between the two. The combinations of these two characters at different degree can occur. Hence there is no reason to distinguish them at the species level. For example in our specimen $04116 / \mathrm{H}$ the shape of the perianth is typically "auriculate", while the majority of the apices of the lobule teeth are simple.

\section{DISCUSSION}

The diversity of Madagascar bryoflora is very high, compared even to continental Africa. From the near 1200 bryophyte species almost 400 are liverworts and hornworts, although the greater part of the island is under high anthropogenic influence. A great proportion of the former primary vegetation types are lost. Many rainforests, which house the highest proportion of the bryophyte species, are already converted to pastures, to secondary savoka bushes, as the result of shifting, slash and burn cultivation and of illegal timber cutting. Even so, careful collection and identification work every year brings to light many new records and even taxa new to science. Therefore the existing protected areas, as national parks and biosphere reserves have great significance and merit international aid to be saved.

As it is seen from the above enumeration, the bryoflora of Madagascar is still inadequately known. From a moderate amount of collections 11 species turned out to be new for the flora of the island and the same amount were known only from one locality. It 
should be mention, that from these few localities already 7 species were described as new to science and further 4 are waiting for description. The herbarium of Eszterházy Károly University in Eger (EGR) has an immense amount of collected specimens (mostly shared with the Herbarium of Tsimbazaza Botanical garden, Antananarivo: TAN). We are looking for specialists of the different groups, especially of mosses and are ready to send the specimens to them for identification and revision, as we already did before.

Acknowledgement - The author wishes to express his gratitudes to all instututions and sponsoring agencies mentioned in his last Madagascar contribution (Pócs 2020b), who supported his travel costs and collecting activities. He is also grateful to his late wife and to his Hungarian and Malagasy colleagues, who participated in the collecting expeditions and finally to the careful reviewers, Catherine Reeb (Sorbonne Université and PC) and to Alfons Schäfer-Verwimp (Herdwangen-Schönach, Germany) for their useful advises and corrections.

\section{REFERENCES}

Allen, B. \& MAGill, R. (2007). A revision of Orthotrichella (Neckeraceae). The Bryologist 110(1):1-45.

Bastos, C.J.P. \& GRadstein, S.R. (2020). The genus Cheilolejeunea (Marchantiophyta: Lejeuneaceae) in tropical America. Nova Hedwigia 111(3-4): 287-335. https://doi.org/10.1127/nova_hedwigia/2020/0596

Bechteler, J., Lee, G.E., Schäfer-Verwimp, A., Pócs, T., Peralta, D.F., Renner, M.A.M., SCHNEIDER, H. \& HEINRICHS, J. (2015). Towards a monophyletic classification of Lejeuneaceae IV: reinstatement of Allorgella, transfer of Microlejeunea aphanella to Vitalianthus and refinements of the subtribal classification. Plant Systematics and Evolution 302: 187-201.

https://doi.org/10.1007/s00606-015-1252-8

Castle, H. (1939). A revision of the genus Radula. Part II. Subgenus Acroradula. Section 1. Epiphyllae. Annales Bryologici 12: 21-47.

Dong, S., Schäfer-Verwimp, A., Meinecke, Ph., Feldberg, K., Bombosch, A., Pócs, T., Schmidt, A.R., Reitner, J., Schneider, H. \& Heinrichs, J. (2012). Tramps, narrow endemics and morphologically cryptic species in the epiphyllous liverwort Diplasiolejeunea. Molecular Phylogenetics \& Evolution 65: 582-594. https://doi.org/10.1016/j.ympev.2012.07.009

Dong, S., Schäfer-Verwimp, A., Pócs, T., Feldberg, K., Czumaj, A., Schmidt. A.R., SCHNEIDER, H. \& HEINRICHS, J. (2013). Size doesn't matter - recircumscription of Microlejeunea (Lejeuneaceae, Porellales) based on molecular and morphological evidence. Phytotaxa 85(2): 41-55. https://doi.org/10.11646/phytotaxa.85.2.2

DorR, L.J. (1997). Plant collectors in Madagascar and the Comoro Islands: A biographical and bibliographical guide to individuals and groups who have collected herbarium material of algae, bryophytes, fungi, lichens, and vascular 
plants in Madagascar and the Comoro Islands. Royal Botanic Gardens, Kew, 524 pp.

GotTsche, C.M., Lindenberg, J.B.W. \& Nees, C.G. (1845). Synopsis Hepaticarum, fasc. 3. Meissner, Hamburg, pp. 305-464. https://doi.org/10.5962/bhl.title.15221

Grolle, R. (1995). The Hepaticae and Anthocerotae of the East African Islands. An annotated catalogue. Bryophytorum bibliotheca 48: 1-178.

He, X.-L. \& Grolle, R. (2001). Xylolejeunea, a new genus of the Lejeuneaceae (Hepaticae) from the Neotropics, Madagascar and the Seychelles. Annales Botanici Fennici 38: 25-44.

Herzog, T. (1947). Hepaticae von der Comoreninsel Johanna. Botaniska Notiser 100(4): 317-334.

Heinrichs, J., Lindner, M., Gradstein, S.R., Groth, H., Buchbender, V., Solga, A. \& FISCHER, E. (2005). Origin and subdivision of Plagiochila (Jungermanniidae: Plagiochilaceae) in tropical Africa based on evidence from nuclear and chloroplast DNA sequences and morphology. Taxon 54(2): 317-333. https://doi.org/10.2307/25065360

Heinrichs, J., Dong, S., Schäfer-Verwimp, A, Peralta, D.F. , Feldberg, K., , Alexander R. SCHMIDT, A.R., \& SCHNEIDER, H. (2014). Towards a monophyletic classification of Lejeuneaceae II: subtribes Pycnolejeuneinae and Xylolejeuneinae subtr. nov., transfer of Otolejeunea to Lepidolejeuninae, and generic refinements. Phytotaxa 163(2): 61-76. https://doi.org/10.11646/phytotaxa.163.2.1

HoDGETTS, N.G. (2008). A morphological revision of the genus Herbertus S.Gray (Herbertaceae, Marchantiophyta) in Africa, including the East African Islands. Journal of Bryology 30: 239-263. https://doi.org/10.1179/174328208X300714

JoNES, E.W. (1953). African Hepatics II. Leptocolea with hyaline-margined leaves. Transactions of the British Bryological Society 2: 144-157.

JoNES, E.W. (1992). African Hepatics XLII. Radula marojezica E. W. Jones, a new species from Madagascar. Journal of Bryology 17(2): 307-311. https://doi.org/10.1179/jbr.1992.17.2.307

Jovet-Ast, S. (1954, "1953"). Le genre Colura, Hepatiques, Lejeuneacees, Diplasiae. Revue Bryologique et Lichénologique 22: 206-312.

KIs, G. \& Pócs, T. (2006). Supplementum and corrections of the non European types and list of exsiccata in the Eger Cryptogamic Herbarium (EGR). Folia Historico Naturalia Musei Matraensis 30: 35-41.

LEE, G.E. \& PóCs, T. (2018). Additions to the distribution of some Palaeotropic Lejeunea (Marchantiophyta) species, with the description of Lejeunea konratii sp. nov. from Fiji. Phytotaxa 349(1): 31-38.

https://doi.org/10.11646/phytotaxa.349.1.3

Lee, G.E., Bechteler, J., Pócs, T., Schäfer-Verwimp, A. \& Heinrichs, J. (2015 online, 2016). Molecular and morphological evidence for an intercontinental range of the liverwort Lejeunea pulchriflora (Marchantiophyta: Lejeuneaceae). Organisms Diversity \& Evolution 16(1):13-21. https://doi.org/10.1007/s13127-015-0243-5

LEHMANN, J.G.C. (1832). Novarum et minus cognitarum stirpium pugillus quartus. Meissner, Hamburg, 64 pp. https://doi.org/10.5962/bhl.title.45011 
Lindner, M., Pócs, T. \& HeinRichs, J. (2004). On the occurrence of Plagiochila stricta on Madagascar, new to Africa. Journal of the Hattori Botanical Laboratory 96: 261-271.

Marline, L., Andriamiarisoa, R. L., Bardat, J., Chuah-Petiot, M., Hedder-son, T. A. J., Reeb, C., Strasberg, D., Wilding, N. \& Ah-Peng, C. (2012). Checklist of the bryophytes of Madagascar. Cryptogamie, Bryologie 33(3): 199-255. https://doi.org/10.7872/cryb.v33.iss3.2012.199

MülleR, F. \& Pócs, T. (2002). Contribution to the hepatic flora of Rodrigues (East African islands). Tropical Bryology 22: 107-113.

ORBÁN, S. (1995). Studies on African Calymperaceae, VI. New data to continental Africa and Madagascar. Acta Botanica Hungarica 39(3-4): 227-234.

ORBÁN, S. (2000). Calymperes venezuelanum, a newly discovered American-African disjunct element in the flora of Madagascar. The Bryologist 103(1): 145-146. https://doi.org/10.1639/0007-2745(2000)103[0145:CVANDA]2.0.C0;2

Pócs, T. (1995). East African Bryophytes, XIV. Hepaticae from the Indian Ocean Islands. Fragmenta Floristica et Geobotanica 40: 251-277.

Pócs, T. (1997). The distribution and origin of the foliicolous bryophyta in the Indian Ocean Islands. - Cryptogams in the Phyllosphaere: Systematics, Distribution, Ecology and Use. Proceedings of the IAB \& IAL Symposium on Foliicolous Cryptogams, 29 August - 2 September 1995, Eger, Hungary. Abstracta Botanica 21: 123-134.

Pócs, T. (2001). East African Bryophytes, XVI. New taxa of Lejeuneoideae (Lejeuneaceae) collected by Patricia Geissler in Manongarivo Special Reserve, NW Madagascar. Candollea 56(1): 69-78.

Pócs, T. (2004). New or little known epiphyllous liverworts, XI. Otolejeunea subana sp. nov. from Madagascar. Acta Academiae Paedagogicae Agriensis, Nov. Ser., Sect. Biol. 25: 49-57.

Pócs, T. (2006a). East African Bryophytes, XX. Observations on some Calypogeiaceae. Acta Academiae Paedagogicae Agriensis, Nov. Ser., Sect. Biol. 25: 29-35.

Pócs, T. (2006b). East African Bryophytes. XXI. Two new species of Telaranea, sect. Tenuifoliae and records on Amazoopsis from the Indian Ocean Islands. Acta Botanica Hungarica 48 (1-2): 119-137. https://doi.org/10.1556/abot.48.2006.1-2.14

Pócs, T. (2006c). East African Bryophytes, XX. Observations on some Calypogeiaceae. Acta Academiae. Paedagogicae Agriensis, Nov. Ser., Sect. Biol. 25: 29-35.

Pócs, T. (2010a). On some less known Lejeunea (Lejeuneaceae, Jungemanniopsida) species in tropical Africa. East African Bryophytes, XXVII (With 9 plates). Nova Hedwigia, Beiheft 138: 99-116.

Pócs, T. (2010b). East African Bryophytes, XXVI. New records from Mayotte (Maore) Island (French Comoro). In: Koponen, T., Pirppo, S. \& ReinikKA, E. (eds.): Dr. Ming-Jou Lai Memorial Volume. Acta Bryolichenologica Asiatica 3: 105114.

Pócs, T. (2011a). Type studies of some African Lejeuneaceae. Acta Botanica Hungarica 53(1-2): 181-192. https://doi.org/10.1556/abot.53.2011.1-2.18 
Pócs, T. (2011b). Bazzania orbanii (Lepidoziaceae), a new species from Madagascar. East African Bryophytes, XXVIII. Acta Biologica Plantarum Agriensis 1: 15-22.

Pócs, T. (2011c). East African Bryophytes XXIX. The Ceratolejeunea (Lejeuneaceae) species in the Indian Ocean islands. Polish Botanical Journal 56(2):131-153.

Pócs, T. (2020a). New or little known epiphyllous liverworts, XXIII. Radula pinnata (Radulaceae), a new species from Madagascar. Hattoria 11: 1-8.

Pócs, T. (2020b). Notes on some species of Colura (Lejeuneaceae, Jungermanniopsida), with description of Colura cataractarum from Madagascar. Acta Botanica Hungarica 62: 393-406.

https://doi.org/10.1556/034.62.2020.3-4.6

Pócs, T. (2020c). Cheilolejeunea hodgettsii sp. nov. with comments on other African members of sect. Cyrtolejeunea. - Notes on the bryophytes of Madagascar 1. Bryophyte Diversity \& Evolution 42(1): 49-55. https://doi.org/10.11646/bde.42.1.4

Pócs, T., Callaghan, A.D., Reeb,C. \& AndriamiarisoA, R.L. (2018). Microlejeunea strasbergii Bardat \& Ah Peng. In: ElLIS, T.L. (ed.): New national and regional bryophyte records, 55. Journal of Bryology 40: 179. https://doi.org/10.1080/03736687.2018.1454161

Pócs, T. \& Geissler, P. (2002). Chapter 3. The bryophytes collected in the Réserve Spéciale de Manongarivo, Madagascar. In: Gautier, L. \& Goodman, S.M. (eds.): Inventaire Floristique et Faunistique de la Réserve Spéciale de Manongarivo (NW Madagascar). Boissiera 59: 41-76.

Pócs, T., Mizutani, M. \& Koponen T. (2019). Bryophyte flora of the Huon Peninsula, Papua New Guinea. LXXX. Cheilolejeunea and Drepanolejeunea, with contributions to Ceratolejeunea, Cololejeunea, Diplasiolejeunea, Lejeunea, Leptolejeunea, Metalejeunea and Microlejeunea (Lejeuneaceae, Marchantiophyta). Acta Bryolichenologica Asiatica 8: 41-84.

Pócs, T., OchyrA, R. \& Bednarek-Ochyra, H. (2016). Lepidozia cupressina (Marchantiopsida, Lepidoziaceae) in sub-Saharan Africa, with a note on the taxonomic status of L. chordulifera. Cryptogamie, Bryologie 37(2):125-147. https://doi.org/10.7872/cryb/v37.iss2.2016.125

Pócs, T. \& PIIPPO, S. (2011). Bryophyte flora of the Huon Peninsula, Papua New Guinea. LXXIV. Cololejeunea (Lejeuneaceae, Hepaticae). Acta Bryolichenologica Asiatica 4: 59-137.

Pócs, T. \& SASS-GyARMATI, A. (2006). New or little known epiphyllous liverworts, XII. Archilejeunea helenae Pócs \& Gyarmati, sp. nova. Cryptogamie, Bryologie 27(1): 103-109.

Pócs, T. \& SchäFER-Verwimp, A. (2006). East African Bryophytes, XXIII. Three new species of Diplasiolejeunea (Lejeuneaceae, Jungermanniopsida) from Madagascar. Cryptogamie, Bryologie 27(4): 439-452.

Pócs, T. \& VÁŇA, J. (2002, "2001"). A new species of Amphicephalozia (Hepaticae) from Madagascar. Polish Botanical Journal 46(2): 145-150.

Pócs, T. \& VÁŇA, J. (2015). East African Bryophytes XXX. New liverwort and hornwort records. Acta Biologica Plantarum Agriensis 3: 3-21.

Pócs, T., Zhu, R-L., Reiner-Drehwald, E., Söderström, L., Hagborg, A. \& von Konrat, M. (2015). Notes on Early Land Plants Today. 71. New synonyms, new names and 
new combinations in Lejeuneaceae (Marchantiophyta). Phytotaxa 208(1): 97-102. https://doi.org/10.11646/phytotaxa.208.1.10

Reeb, C., Marline, L., Rabeau, L., Andriamanantena, A., AndriamiarisoA, R.L., RanarijaonA, H-L. \& Pócs, T. (2018). A survey of Marchantiales from Madagascar. Acta Biologica Plantarum Agriensis 6: 3-72.

ReEb, C., Letsara, R. AndriamiarisoA, R.L., Brinda, J.C., ABAlo-LoKo, G.-A., BoucheronDubuisson, E., Fischer, E., Hodgetts, N.G., Lavocat-Bernard, E., Naniarimino, F., Phillipson, P.B., Sass-Gyarmati, A. \& A. Vanderpoorten, A. (2019). Un atelier pilote sur les Bryophytes a l'herbier d'Antananarivo (TAN) met en évidence la présence de 7 espèces supplémentaires a Madagascar. Candollea 74: 153-158. https://doi.org/10.15553/c2019v742a5

SASS-GyARmati, A. (2001). Lopholejeunea leioptera Gyarmati (Lejeuneaceae, subfam. Ptychanthoideae), une nouvelle espèce récoltée dans la Réserve Spéciale de Manongarivo (Nord-Ouest de Madagascar). Candollea 56(1): 79-83.

Sass-Gyarmati, A. \& Pócs, T. (2002). A second species of Symbiezidium from Africa. Cryptogamie, Bryologie 23(1): 31-39.

SASS-GyARmATI, A. (2017). Bazzania konratiana sp. nov. (Marchantiophyta: Lepidoziaceae) from Madagascar. Cryptogamie Bryologie 38(2): 119-124. https://doi.org/10.7872/cryb/v38.iss2.2017.119

Sass-Gyarmati, A. \& Pócs, T. (2019): A new combination in Lepidoziaceae (Marchantiophyta). Phytotaxa 403: 142.

https://doi.org/10.11646/phytotaxa.403.2.8

SCHUSTER, R.M. (1963). An annotated synopsis of the genera and subgenera of Lejeuneaceae. I. Introduction; annotated keys to subfamilies and genera. Beihefte zur Nova Hedwigia 9: 1-203.

Söderström, L., Hagborg, A., von Konrat, M., Bartholomew-Began, Sh., Bell, D., Briscoe, L., Brown, E. ${ }^{\dagger}$, Cargill, DC., Costa, D.P., Crandall-Stotler, B.J., Cooper, E.D., Dauphin, G., Engel, J.J., FeldberG, K., Glenny, D., Gradstein, S..R., He, X., Heinrichs, J., Hentschel, J., Ilkiu-Borges, A., Katagiri, T., Konstantinova, N.A., Larraín, J., Long, DG., Nebel, M., Pócs, T., Puche, F., Reiner-Drehwald, E., Renner, M.A.M., Sass-Gyarmati, A., SchäFer-Verwimp, A., Segarra, J.G.M., Stotler, R.E. ${ }^{\dagger}$, Sukkharak, Ph., Thiers, B.M., Uribe, J., Vaña, J., Villareal, J.C., Wigginton, M., ZHANG, L. \& ZHU, R.L. (2016): World checklist of hornworts and liverworts. PhytoKeys 59: 1-828. https://doi.org/10.3897/phytokeys.59.6261

StEPhani, F. (1916) Species Hepaticarum 5 Genève \& Bâle, George \& Cie, pp. 8331008. https://doi.org/10.5962/bhl.title.95494

Szabó, A. \& Pócs, T. (2016). New or little known epiphyllous liverworts, XX. Cololejeunea nosykombae A. Szabó \& Pócs sp. nov. from Madagascar. Journal of Bryology 38(4): 302-307. https://doi.org/10.1080/03736687.2016.1156357

TixIER, P. (1977). Espèces nouvelles malgaches du genre Diplasiolejeunea (Spruce) Schiffn. (Hepaticae). Lindbergia 4: 117-125.

TixieR, P. (1979). La famille des Cololejeunoideae Grolle dans l'Océan Indien Occidental. - Essai monographique. Bulletin de l'Academie Malgache 55: 173247.

Tixier, P. (1985). Contribution à la connaissance des Cololejeuneoideae. Bryophytorum Bibliotheca 27: 1-439. 
Wigginton, M. J. (2018). Checklist and distribution of the liverworts and hornworts of sub- Saharan Africa, including the East African Islands. Tropical Bryology Research Reports 9: 1-138.

WILDING, N. (2016). Systematics, biogeography and morphological evolution in Entosthodon Schwägr. (Bryopsida, Funariaceae) with a revision of the genus in Africa. University of Cape Town, 330 pp.

(submitted: 04.12.2020, accepted: 23.12.2020) 